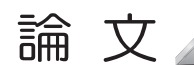

Original Paper

\title{
通気網解析技術の大空間を含む地下構築物への適用*
}

\author{
坂 井 哲 郎 $^{1}$ 冨 田 新 二 $^{2}$ 芳 賀 佳 $之^{3}$
}

\section{Application of Mine Ventilation Network Analysis Technique to Underground Civil Construction Including Large Geo-Space}

by Tetsuo SAKAI ${ }^{\mathrm{a}}$, Shinji TOMITA ${ }^{\mathrm{b}}$ and Yoshiyuki HAGA ${ }^{\mathrm{c}}$

a. Mitsui Mining Engineering Co., Ltd., 1-3-1, Hatchobori, Chuo-ku, Tokyo, 104-0032, Japan

(Corresponding author : E-mail T.Sakai@mmec.co.jp)

b. Japan Coal Energy Center

c. Hazama Corporation

In the civil engineering construction field, it is often necessary to determine the ventilation requirements in order to maintain a minimum air quality for human breathing. This needs to take into account dilution of natural gushed gas and the exhaust gases from diesel equipment, the gases produced by the detonation of explosives and their dissipation time, as well as the dust generated by shotcreting. The purpose of such a ventilation plan is to specify the capacity and optimum location of the ventilation equipment, both of which are calculated simply.

Recent large-scale underground excavations such as power plant, energy storage, and so on, consist of complex lay-outs, deeply seated long openings, and substantial excavation volumes. Hence, they require rather sophisticated ventilation programs because of their huge pressure losses and air handling volumes.

The authors have applied coalmine ventilation technology to optimize the ventilation plan for such large-scale underground civil constructions. A quasi-three-dimensional ventilation network analysis method has been developed and applied to analyze the airflow in large scale geo-spaces.

KEY WORDS : Geo-Spaces, Quasi-three-dimensional Ventilation Network Analysis, Optimized Ventilation Plan, GEOVNT, Computational Fluid Dynamics

\section{1.は じめに}

一般に土木分野における地下構築物の通気量は, 自然発生ガス ( 可燃性ガス, 酸欠空気等) の希釈, 重機の排気ガス $\left(\mathrm{NO}_{\mathrm{x}}, \mathrm{CO}\right)$ 希釈，発破後ガス換気時間，吹付粉じん管理濃度等を勘案し，そ の最大值に坑内人員の呼気必要量を加えて切羽必要風量として いる。通気計画は風管漏風を考慮し, 切羽必要風量を確保するの に必要なファン能力の算定が主体となっている。しかし土木トン ネル等, 地下構造が単純な場合は通気計画は比較的容易である が, 地下発電所, 石油や LPG 備蓄基地等の大規模地下空間および これを取り巻く多くの坑道群を持つ地下構築物においては, 必要 風量が大きく空気の流動に伴う圧力損失も大きいため, 工事の進 渉ごとの合理的な通気計画が必要となる。また近年，作業箇所の 粉じんや熱環境などに対する作業環境改善気運が高まり, コスト 削減への必然性も踏まえ, より緻密な通気計画の立案が要求され ている。

筆者らはこれらの要求に応えるため，大規模地下空間および複 雑な通気回路を持つ地下構築物建設工事に対し，簡易かつ実用上 十分な精度を有する通気網解析を行い，施工ステップごと（ 通気

* 2002 年 1 月 30 日受付 2003 年 1 月 23 日受理

1. 普通会員 三井鉱山エンジニアリング(株) 資源開発第一部 副部長 九州大 学大学院 工学府 博士後期課程

2. 普通会員 (株) 石炭エネルギーセンター 企画部

3. (株) 間組 小丸川作業所 機電課長

[ 著者連絡先 ] FAX 03-5540-6786（三井鉱山エンジニアリング・坂井） E-mail : T.Sakai@mmec.co.jp

キーワード : 地下大空間, 疑似三次元通気網解析, 適正通気システム, GEOVNT, 数值流体力学解析
的イベントごと）に適正通気システムの検討を実施した。特に大 空間の通気には疑似三次元通気網解析の適用を試み, 空間と坑道 を同時に解析できる通気網解析プログラム (GEOVNT) と, 数值流 体力学 (Computational Fluid Dynamics-CFD) 解析による解析結果と 比較して解析精度を評価した。さらにフォローアップ調査として 建設途上の通気測定を行い，解析結果を再評価した ${ }^{1)}$ 。本稿では 本件に係わる一連の通気網解析を通し, 通気技術の新たな展開手 法について報告する。

\section{2. 対象とした地下構築物の換気システムの概要}

今回, 検討対象とした地下構築物は, 幅約 $24 \mathrm{~m}$, 高さ約 $48 \mathrm{~m}$, 長さ約 $190 \mathrm{~m}$ の発電所大空間と, これを取り巻く調查坑, 機器搬 入トンネル, 放水路トンネル等の長距離の坑道群から構成される (図 1 参照)。取水口から発電所大空間までの落差は $700 \mathrm{~m}$, 放水 路トンネルは約 $2 \mathrm{~km}$ に達する。すべての坑道は中腹の坑口から掘 削され，また入排気もすべてこの坑口 (群) で行われる。

当初の通気計画においては, これらの坑道の通気は坑口の入気 ファンと切羽に設置した排気ファン, および長距離風管による局 部通気法であった。また大空間は空間入口に設置した局部ファン から風管で切羽を吹かし，大空間の上方の上部調查坑と大空間入 口で連接された排気立坑から排気を行う方法で ( 図 2 参照), 盤下 げ工事段階で必要な $4,000 \mathrm{~m}^{3} / \mathrm{min}$ 以上の風量確保が困難, かつ大 量の入気が直接排気立坑に短絡するなど, 通気挙動が非合理的で あった。このほかに当初の通気計画では, 風管抵抗が大きく多数 の切羽の必要風量確保が困難なこと, またファン台数が多いこと などの課題があった。 


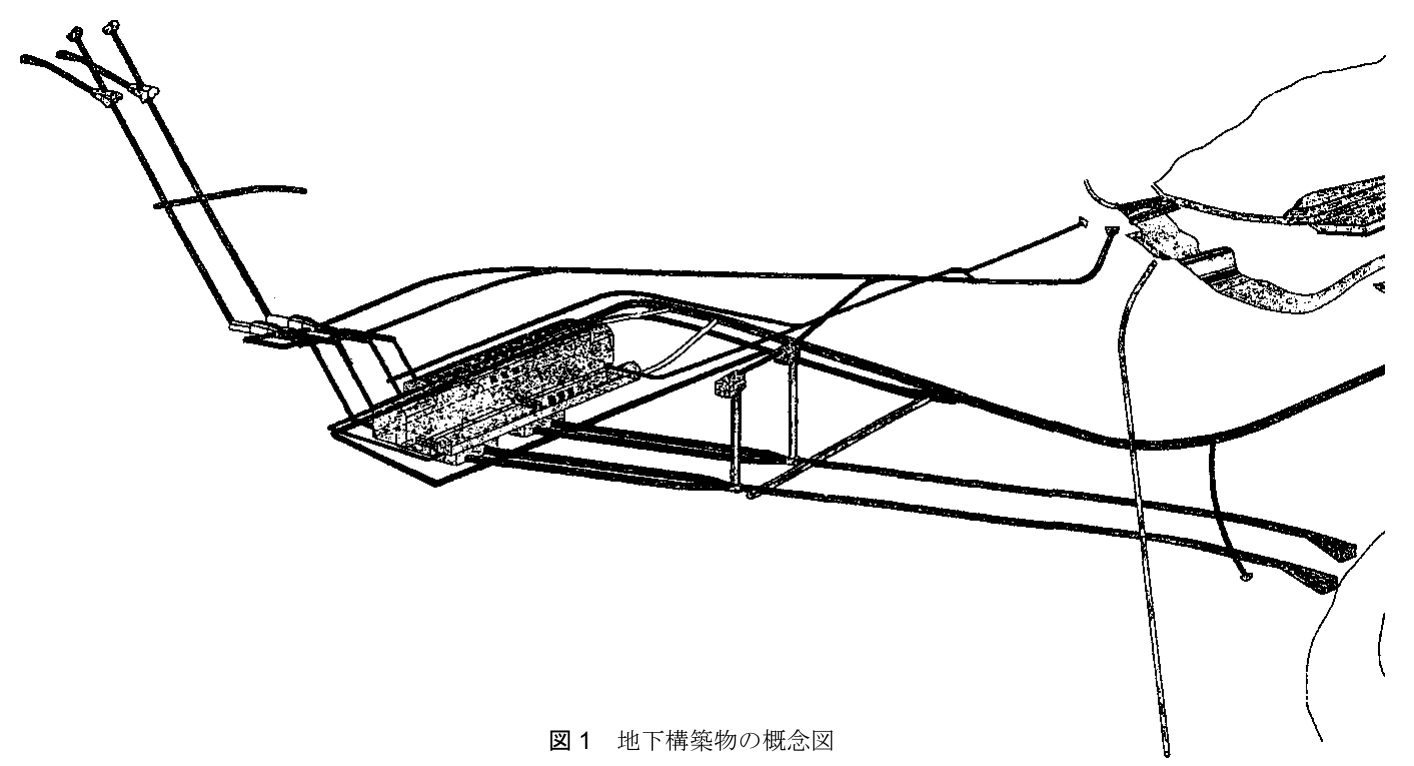

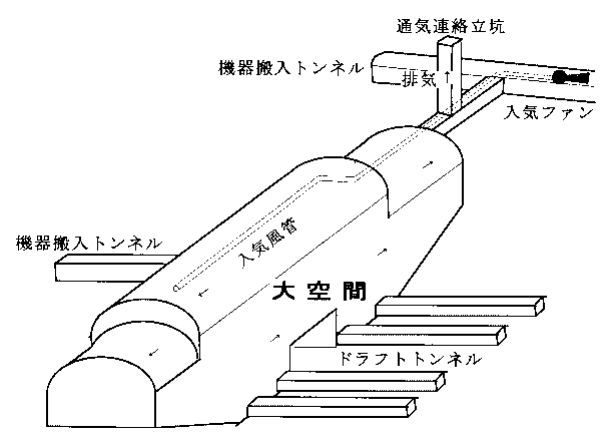

図 2 大空間の通気システム

\section{3. 通気網解析}

\section{$3 \cdot 1$ 通気網解析手法}

解析は, 地下構築物中央部で被りが厚くなるものの地熱勾配は 小さいため熱環境解析は行わず，九州大学の井上助教授が開発し た「風丸Windows版」を用いて風量解析を行った。ただし特にダ ンプトラックの排気ガスによる温度上昇が懸念されたため, 標準 状態での風量と高温の排気ガス量の比から気流中温度を計算し, 風丸の入力温度に反映させた。解析ケースは, 工事進渉状況に応 じて坑道の貫通等の通気的イベントごとに 6 段階に分け，通気抵 抗低減のために坑道通気方式を多用した。しかし炭鉱等の通気網 解析と異なり，構造上風管通気の解析が大きな比重を占めた。

大空間の通気挙動解析手法には一般に CFD が用いられるが，多 くのケーススタディを必要とする坑内通気設計には，膨大な時間 を要し実用的でない。水田ら $(1990)^{2)}$ は工場の閉鎖空間を多くの 直方体要素で三次元的に離散化して, 気流挙動と熱環境の解析を 試みているほか，張ら (1996) $)^{3)}$ は大空間の仮想風道モデルにおけ る空気の粘性を考慮した摩擦係数の算出と気流および熱環境の解 析を行っている。しかしいずれも大空間のみを取り扱っている。 今回の解析では，作業環境の予測のために大空間内における風量 分布を知る必要があったため, 大空間と坑道群が一体になった通 気網での解析を行うこととした。大空間部は縦断面を約 $8 \mathrm{~m} \times 15$ $17 \mathrm{~m}$ の 9 の断面に分割し，また大空間長軸方向を 11 断面で切っ て, それぞれの小空間を架空の坑道で代表させた三次元的な通気 網モデルを構築した（以下，疑似三次元通気網と言う)。このと き, 1 つの小空間は 3 軸方向の架空坑道で構成されることになる。 なお, 工事最終段階における通気網モデルの節点数は 201, う
表 1 摩擦係数

\begin{tabular}{ll|cc}
\hline & & $K\left(\mathrm{kgw} \cdot \mathrm{s}^{2} / \mathrm{m}^{4}\right)$ & $\lambda$ \\
\hline 大空間 & 周囲が空間 & 0.0001 & 0.007 \\
& 1 面が壁面 & 0.0003 & 0.020 \\
& 2 面が壁面 & 0.0005 & 0.033 \\
通常坑道 & 次き付け坑道 & 0.0010 & 0.065 \\
& 覆工坑道·立坑 & 0.0008 & 0.052 \\
& & 0.0003 & 0.020 \\
\hline
\end{tabular}

ち坑口節点 10 , 坑道数は 376 本となった。

\section{$3 \cdot 2$ 解析パラメータの設定}

$3 \cdot 2 \cdot 1$ 摩擦係数 大空間を構成する架空坑道の摩擦係数 ( $K$ 值 $)$ は，壁面の全部または一部が空気であるため，計算上十分 に小さいと思われる值とした。表 1 に今回使用した大空間架空坑 道, 通常坑道, 風管の摩擦係数を示す。特に風管の摩擦係数は, 材質, 施工状態, 使用期間等によって異なるが, 新品ビニール風 管の平均的な施工状態と仮定した。なお土木分野では摩擦係数は 通常 $\lambda$ 值 (水力学で用いる摩擦係数で, ディメンションを持たない) で示されるため, ここでは $K$ 值と $\lambda$ 值を併記する。

$3 \cdot 2 \cdot 2$ 漏風率長距離風管通気では漏風率の見積もりが 重要となるが，これも施工状態により大きく異なる。 $100 \mathrm{~m}$ 当た り漏風率を $\beta$, 風管長を $L$ と寸れば, 漏風率 $m$ は通常下記の式を 用いて算出される ${ }^{4)}$ 。

$m=\beta \times L / 100$

本式では，風管単位長さ当たりの漏風量を一定としており，あ る距離で漏風率 $100 \%$, 寸なわち風管風量が 0 となる。実際には 長距離風管においては圧力損失によりファンから離れるに従って 漏風量は減少していく。このため, 風管内風量に対する漏風率が 一定となるよう，次式により漏風量を求めた。

$m=1-(1-\beta)^{L / 100}$

漏風率は, 張力がある場合のビニール風管では, 施工良好な場 合で $100 \mathrm{~m}$ 当たり $1.5 \%$, 施工不良の場合 $3 \%$ と言われている ${ }^{5,6}$ 。 ここでは平均的な值として，2\%の值を用いた。

解析モデル上で風管漏風を考慮するためには, 風管単位長さご とに漏風回路を設ければ良いが，回路が複雑となる。したがって 風管中間点に漏風回路を設け，漏風を代表させた。

\section{$3 \cdot 3$ 必要風量の算出}

切羽の必要風量は, 大規模な発破が行われる発電所大空間の盤 


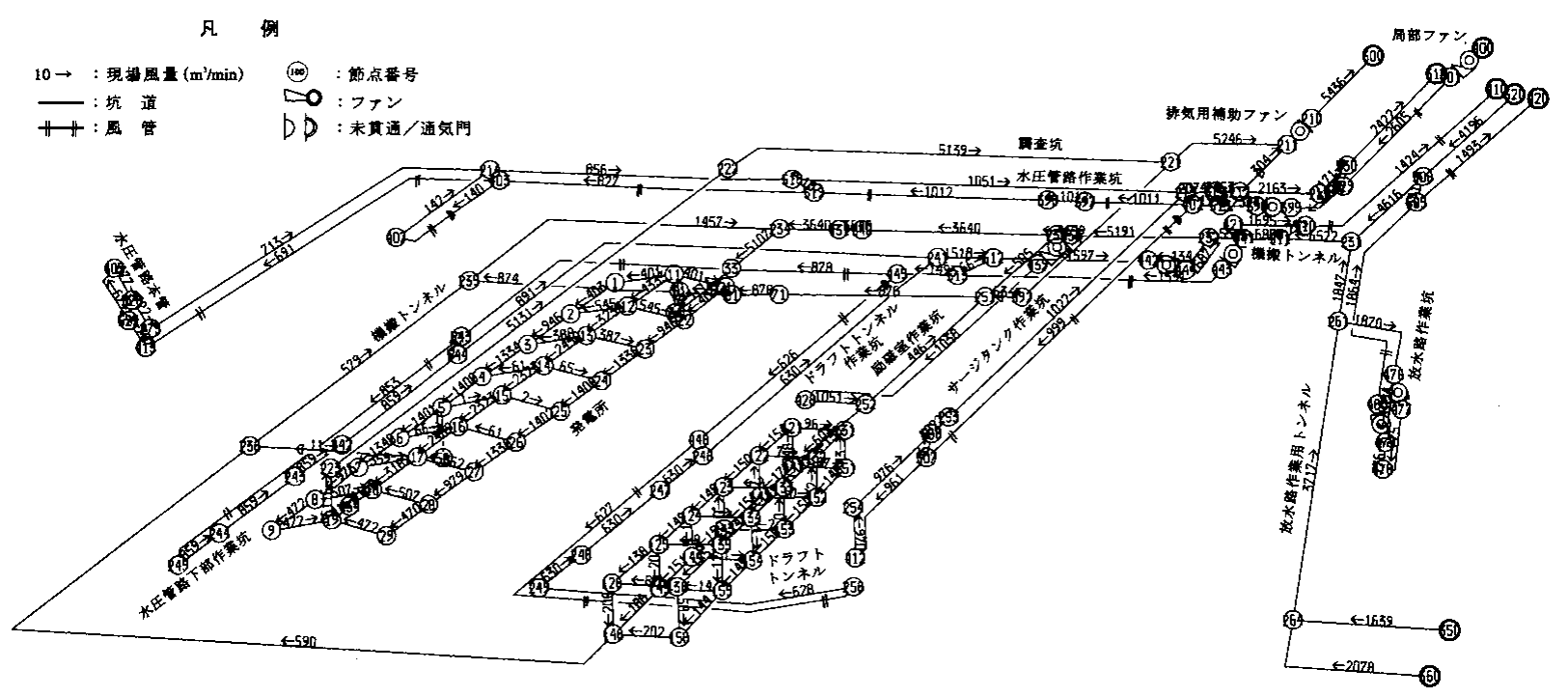

図 3 施工ステップ 2 の通気網解析図

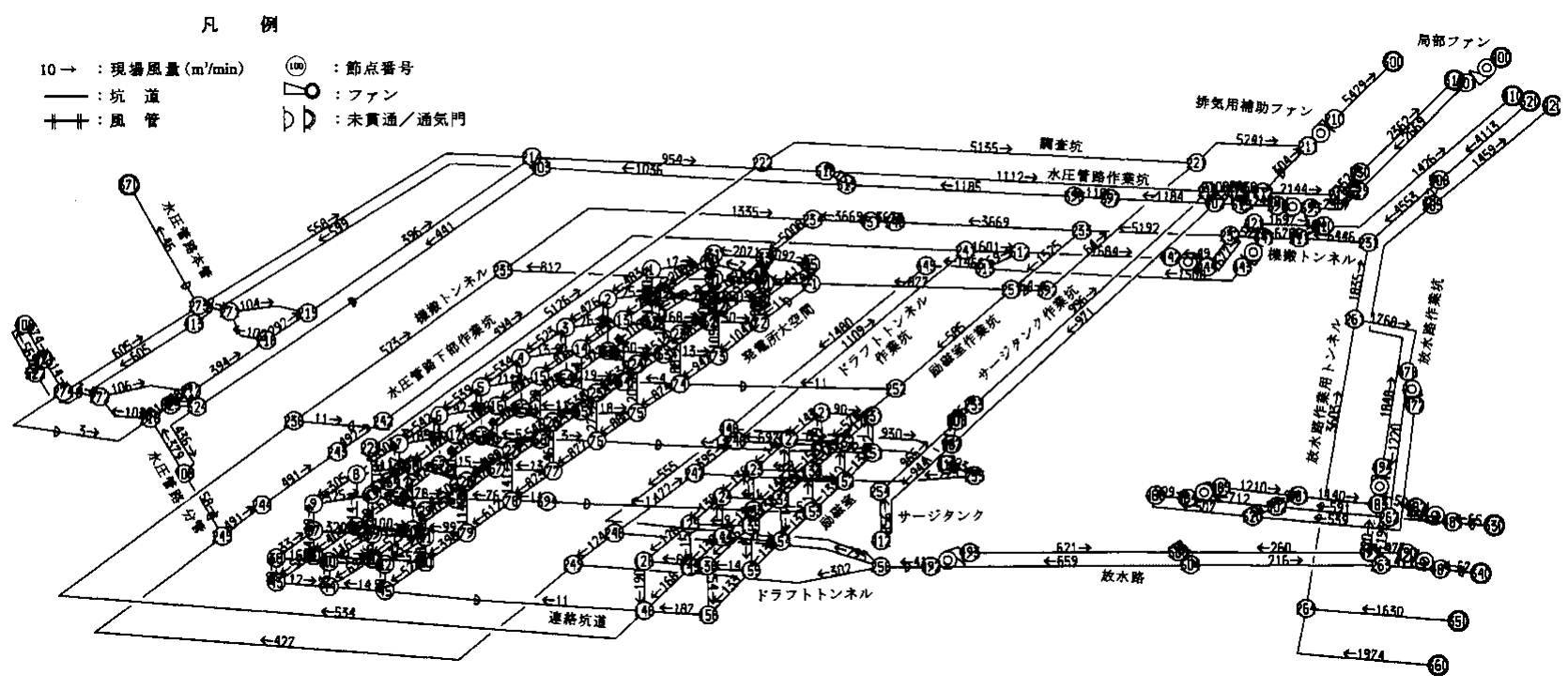

図 4 施工ステップ 3 の通気網解析図

下げを除き, 重機排気ガス希釈が最大必要風量のファクターとな り，これに呼気必要量を加えて $500 \sim 1,000 \mathrm{~m}^{3} / \mathrm{min}$ となった。な お, 大空間下部盤下げ時は, 発破ガス希釈が最大ファクターとな り, 約 $4,300 \mathrm{~m}^{3} / \mathrm{min}$ となった。

\section{4. 解 析 結 果}

上記設定条件の下に, ファン, 風管長, 通気門等の通気設備が ミニマイズできるようにステップごとの通気計画を策定し，それ に対応した解析モデルを構築して通気網解析を実施した。解析は ファンの数, 能力, 風管径や各所の抵抗を変化させて, 多くのケー ススタディを行い, 最終的に風管漏風を考慮しつつ切羽に必要風 量を確保するための適正なファンの能力と配置計画を策定した。 以下に各施工ステップごとの解析結果とその評価を示す。

\section{$4 \cdot 1$ 各施エステップごとの解析結果}

施工ステップ 1 においては, ほとんど掘進坑道から構成される 施工ステップで, 坑道の用途により, 2 切羽は坑口からの押込風 管通気, 1 切羽は坑道入気 + 押込風管通気, その他は坑道入気 + 吸 出風管排気とした。

図 3 に施工ステップ 2 の解析図を示す。この施工ステップでは
すでに通気立坑を経由した補助ファンによる坑道通気回路が完成 しており，大空間上部の掘進 ( 拡幅工事 ) が展開されている状態 である。通気システムの設定に当たっては, 種々のケーススタディ の結果, 最終的に立坑位置を変更し, 補助ファンによる坑道通気 を採用して，入気ファンを用いずに大容量 $\left(5,000 \mathrm{~m}^{3} / \mathrm{min}\right)$ の風量 が確保できるシステムとした。また補助ファンの位置もメンテナ ンスの容易性や騒音を考慮し, 立坑と坑口の中間点とした。解析 の結果, 主要入気回路となる機搬トンネルから $4,196 \mathrm{~m}^{3} / \mathrm{min}$ 入り, 補助ファンで $5,436 \mathrm{~m}^{3} / \mathrm{min}$ 排気される結果となった。

図 4 に施工ステップ 3 の解析図を示す。このステップでは基本 的な通気回路が構成され，一部掘進と発電所盤下げ等が行われて いる。水圧管路や放水路トンネルが貫通しているが，J/V工事区 が異なるため, 通気的には独立しており，すべて坑口からの入排 気システムとした。大空間は中央部まで掘り下がっているが, 連 絡坑道とは貫通していない状態である。貫通した下部水圧管路作 業坑のループ回路の重機排ガス希釈のため, サージタンク下部へ の局部通気量を調整することで, ループ回路の必要風量 $500 \mathrm{~m}^{3}$ / min を確保することができた。

施工ステップ 4 においては, 大空間下部等を残しほとんどの坑 


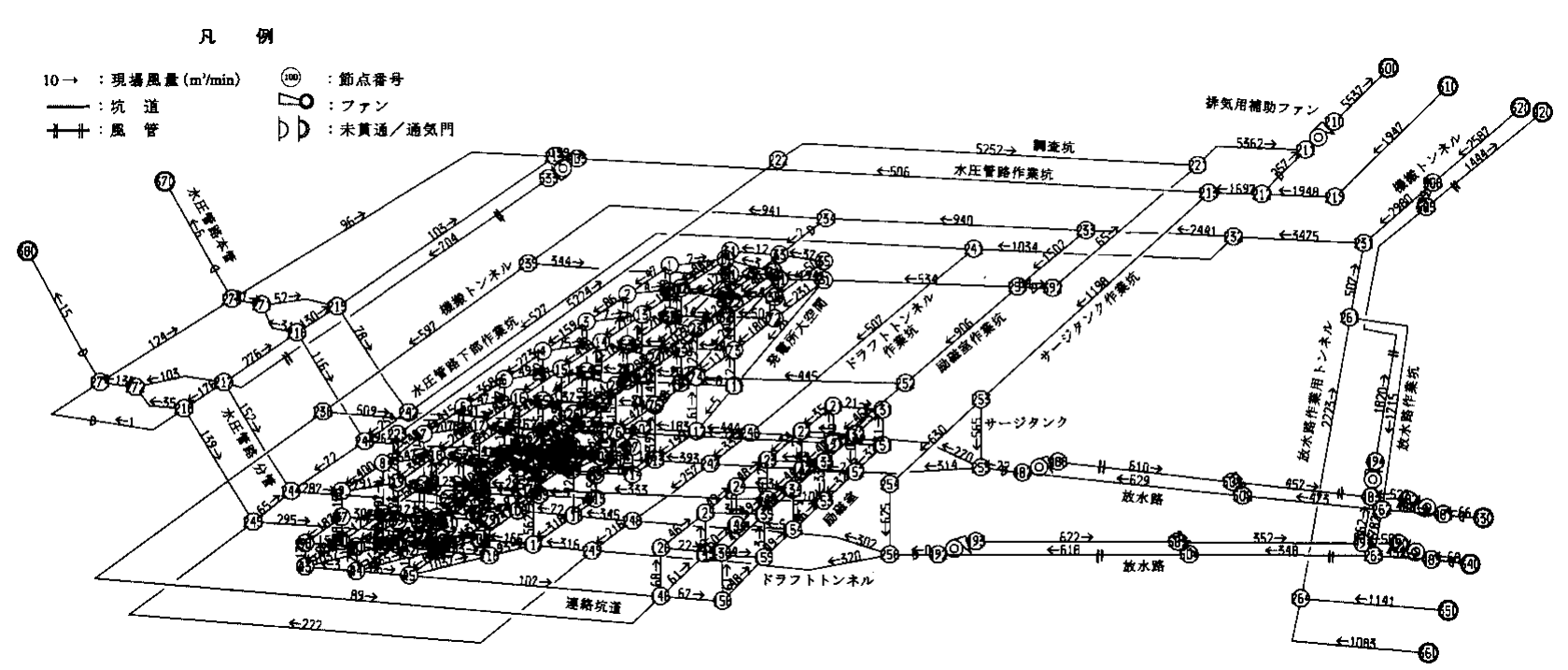

図 5 施工ステップ 5 の通気網解析図

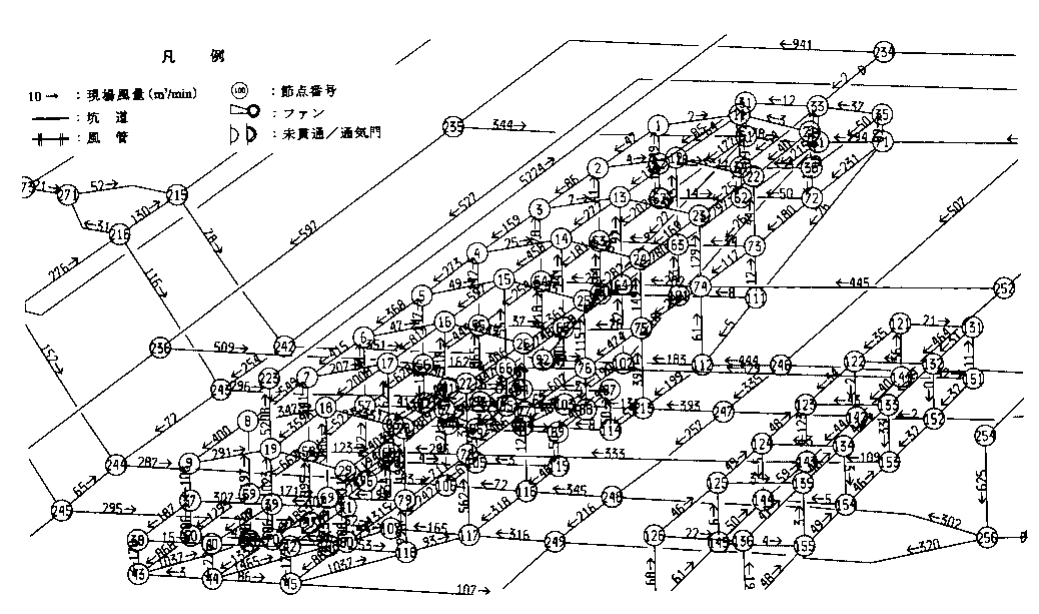

図 6 施工ステップ 5 の大空間網解析拡大図

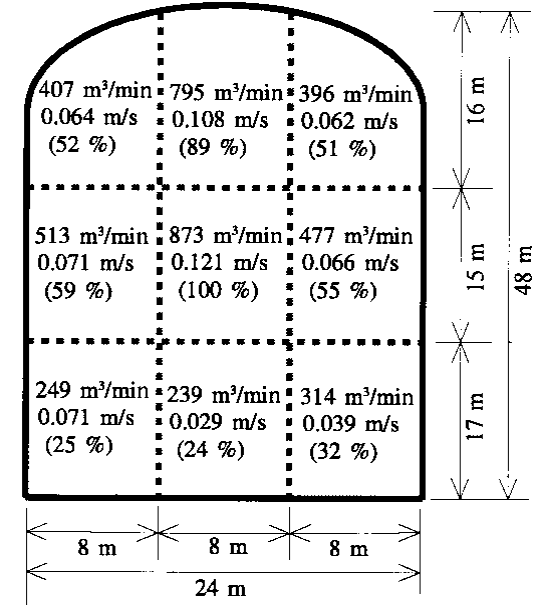

図 7 中央綐断面の風量と風速分布
道掘進が完了している。このステップで主体となる覆工工事等の 風量確保のため, 貫通した各連絡坑道を開放して大空間内に 5,098 $\mathrm{m}^{3} / \mathrm{min}$ の風を流すことができた。現場的なファンの移設工数削 減のため, ステップ 1 から 4 まで, 通気システム自体はほとんど 変化しないように策定した。

図 5 は施工ステップ 5 の解析図である。掘進工事はすべて完了 し, $\mathrm{J} / \mathrm{V}$ の異なる工事区を除き, 1 台の補助ファンで地下構築物 全体の通気が可能となっている。このときの総排気風量は 5,400 $\mathrm{m}^{3} / \min$ となっている。

施工ステップ 1 から施工ステップ 4 においては, 長距離風管通 気を多用しているため圧力損失と漏風が多く, 坑道断面設計上可 能な限りの風管径増大措置により漏風を防止する計画とした。

\section{$4 \cdot 2$ 大空間の解析結果}

疑似三次元通気網解析の結果, 大空間の気流は壁面側で流れに くく中央部で流れや寸い傾向が顕著に現れた。図 6 にステップ 5 における大空間の解析拡大図を示す。また図 7 にこのときの大空 間中央縦断面の風量と風速，および中央架空坑道の風速に対する 周辺架空坑道の風速の比率 (\%) を示す。この断面においては，合 計で $4,263 \mathrm{~m}^{3} / \mathrm{min}$ 流れているが，下部の風速は中央部の $24 \sim 32$ $\%$ しかなく, また壁側架空坑道も $51 \sim 59 \%$ に止まっている。後 述する大断面機搬トンネルでの風速分布測定結果 (図 15 参照) に 比べ下部および壁面の風速が小さいが，これは下部の形状が複雑
であることと排気が大空間最奥部の上部に位置する通気立坑から 吸い込まれているためで, 気流の流れを良く表現している。今後, より実測值に近い風速分布を示すように， $3 \cdot 2 \cdot 1$ で設定した架 空坑道の摩擦係数を検討する考えである。

次に節点解法では抵抗值が著しく小さい場合, 逐次計算が収束 しにくい傾向がある。今回の解析では大空間を $K$ 值の小さい架空 坑道のメッシュで構成しているため, 最小抵抗值は 0.001 murgue 以下となり, 解析パラメータを変化させても誤差が数 $\mathrm{m}^{3} / \mathrm{min}$ か ら数 $10 \mathrm{~m}^{3} / \mathrm{min}$ 以下に収束しない状況が生じた。このため, 大空 間を構成する架空坑道のすべての坑道抵抗を 10 倍, 100 倍, 1,000 倍して解析すると, 倍率を大きくするにつれ収束性が向上し, 最 小抵抗が 0.1 murgue 程度となったときにほぼ気流は安定し, かつ 良好な収束性を示した。このときの大空間の入排気総量の差は, いずれのケースでも $2 \sim 3 \mathrm{~m}^{3} / \mathrm{min}$ 以内に止まった。これは実質的 に許容誤差範囲内と考えられる。この手法については, 筆者が行っ た高地温条件下における金属鉱山の採掘後大空洞の解析において も同様な結果を得ている ${ }^{7,8)}$ 。井上ら ${ }^{9)}$ は, 節点解法を用いて通気 網解析を行う場合の入力值と解析速度および収束性について詳細 に検討しているが，微小な圧力損失は計算の収束性を悪化させる 原因の一つであるとして, 圧力損失が $10^{-5} \mathrm{mmAq}$ 以下の場合に正 しい風量を求めるためには, 計算ではこれ以下の值を取り扱う必 要がある, としている。今回の大空間モデルにおいては $10^{-4} \sim$ 
$10^{-5}$ murgue, 圧力損失が最小 $10^{-10} \mathrm{mmAq}$ という小さな值となっ ており,このときに発生する圧力損失の変化は極めて微小であり, 収束性の悪化を招いたと考えられる。このような場合には抵抗值 を便宜上増加させても解析結果に与える影響は小さく, 収束性が 改善されることが実証された。

また空洞下層部と上層部に $3{ }^{\circ} \mathrm{C}$ 以上の温度差を設定すると, 空 洞内で著しい量の風が乱流現象を示し, 収束性の悪化を招いた。

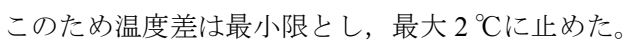

なお，図 6 に示寸施工ステップ 5 では，大空間内設備工事のた めにいくつかの連絡坑を閉塞し, 下部より低温の風を入れて上部 より温度上昇した排気を抜く通気エネルギー的に望ましいシステ ムとなっている。

\section{5. 疑似三次元通気網解析の検証}

\section{$5 \cdot 1$ GEOVNT}

次に疑似三次元通気網解析による大空間の解析結果の評価のた め, (財) エンジニアリング振興協会の委託研究の一環として当社 等が開発した，二層ゾーンモデル解析手法と通気網解析手法を融 合した解析プログラム $(\mathrm{GEOVNT})^{10)}$ で大空間を含む坑内全域の気 流挙動解析を実施した。このプログラムの特徵は, 空間部の任意 の節点に坑道の節点解法により求められた節点圧力を与えること によって, 空間内の通気流の解析と坑道の通気流の解析を同時に 実施することができることにある。筆者らは本プログラムを用い て, 大深度地下開発におけるジオ・ドームの火災時気流挙動のケー ススタディを行い, 通気制御による防災システム構築に寄与して いる。ただし本プログラムの空間部の解析手法は火煙の流動解析 を行う二層ゾーンモデルを用いているため, 今回の温度差のない 大空間内の気流挙動を解析することはできない。このため本プロ グラムでは, 地下構築物全体の通気挙動について比較評価すると ともに，大空間を抵抗 (壁面)のない 9 つの連続した小空間に分 割し, 坑道と空間の空気の出入りと大空間の水平方向の空気の流 れを解析して，比較評価を行うこととした。図８に大空間内部の 解析結果を, 図 9 に地下構築物全体の解析結果を示寸。なお解析 モデルは施工ステップ 5 のみについて構築, 解析した。

解析の結果, 地下構築物全体の風量バランスは主要坑道につい ては節点解法による通気網解析結果との平均誤差が $7.7 \%$ とおお むね一致したほか, 大空間の風量の入出量もおおむね一致した。 このことは, 疑似三次元通気網を含む今回モデルの節点解法によ る解析が妥当な手法であることを示している。

\section{$5 \cdot 2$ 数值流体力学解析}

次に, 空間の汎用的な流体挙動解析手法による検証として, 3 次元汎用熱流体解析コード (PHOENICS) を用い, 空間部のみの数 值流体力学 (CFD) 解析を実施した。CFD 解析では, 大空間と繋が る長距離かつ複雑な坑道群をも解析の対象とすることは不可能で
はないが，膨大な労力とコストを要するため現実的ではない。し たがって, 通常は解析条件を与えて大空間のみの気流挙動評価に 用いられるが，境界条件が正しければ正しい解析結果が得られる ことは，模型実験や現場計測で実証されている（例えば中山ら $(2002)^{11)}$ など)。ここでは節点解法による通気網解析結果から, 坑 道の大空間開口部節点の圧力と風速を境界条件として与えて大空 間のみの気流挙動を評価した。また CFD 解析はモデル構築および 解析に多くの時間を要するため, 代表例として施工ステップ 4 と 施工ステップ 5 についてモデルを構築, 解析を実施した。なお, $\mathrm{CFD}$ 解析は九州大学大学院工学研究院地球資源システム工学部門 に委託して実施した。

CFD による解析モデルでは, メッシュ数約 83,000 で, 壁面に貫 通した坑道近傍ではメッシュ幅は $1 \mathrm{~m}$ 以下, 遠方では $3 \mathrm{~m}$ とした。 入力データは入気風量 (風速) および $20{ }^{\circ} \mathrm{C}$ 標準状態の空気とし, 重力は考慮していない。解析時間は 20 時間/回 (収束は 5 桁とし た )であった。

図 10 に施工ステップ 5 の発電所中央鉛直断面の気流挙動の解 析結果を, 図 11 に発電所連絡坑と機搬トンネルを通る水平断面 の気流挙動を示す。矢印は気流ベクトル方向および風速の大きさ を示す。

解析の結果, 約 $5,000 \mathrm{~m}^{3} / \mathrm{min}$ の風量が流れていても空洞断面が 大きいために, 風速 $0.3 \mathrm{~m} / \mathrm{s}$ を確保できるのは各連絡坑から気流 が吹き込む局部のみであり，その他の箇所ではおおむね中央部付 近で $1 \times 10^{-1} \sim 6 \times 10^{-2} \mathrm{~m} / \mathrm{s}$, 壁面近傍では $6 \times 10^{-2} \sim 3 \times 10^{-2} \mathrm{~m}$ $/ \mathrm{s}$, 大空間下部では $3 \times 10^{-2} \mathrm{~m} / \mathrm{s}$ 以下となった。この值は図 7 の 疑似三次元通気網解析による風速分布の傾向に一致している。し かし CFD解析では各連絡坑道から流入する風の風向方向のベクト ルが大きく, 対面の壁面にぶつかって急速に風速を減じ, 壁面に 沿って流動したり空間内を旋回寸る傾向が顕著に現れている。こ のことから, 疑似三次元通気網解析は, 空間全体の通気流の挙動 を大きく見るためには簡易で実用上問題のない精度を有する解析 手法であることが検証されたが, 空気の動圧, 慣性力による局所 数字は風量 $\left[\mathrm{m}^{3} / \mathrm{min}\right]$

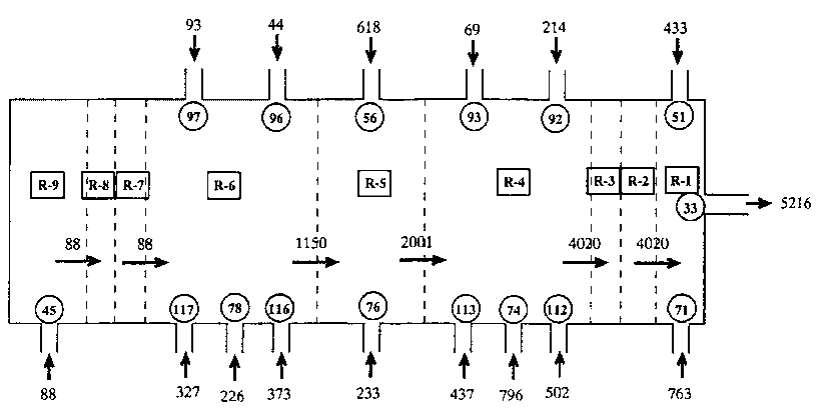

図 8 GEOVNT による大空間解析結果

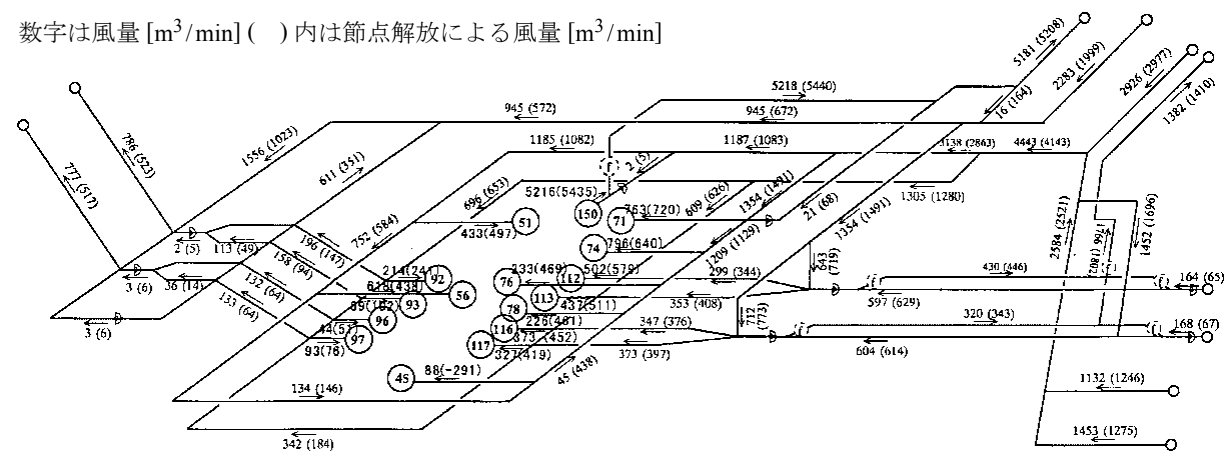

図 9 GEOVNT による地下構築物全体の解析結果 


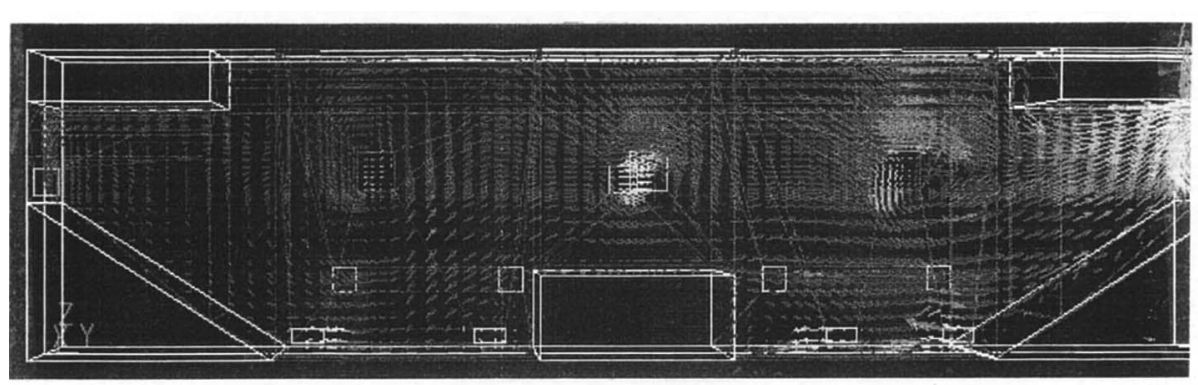

図 10 大空間の中央鉛直断面 CFD 解析図

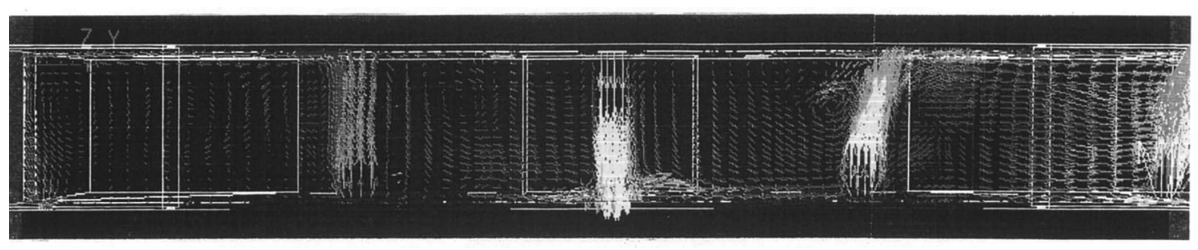

図 11 大空間の水平断面 $\mathrm{CFD}$ 解析図

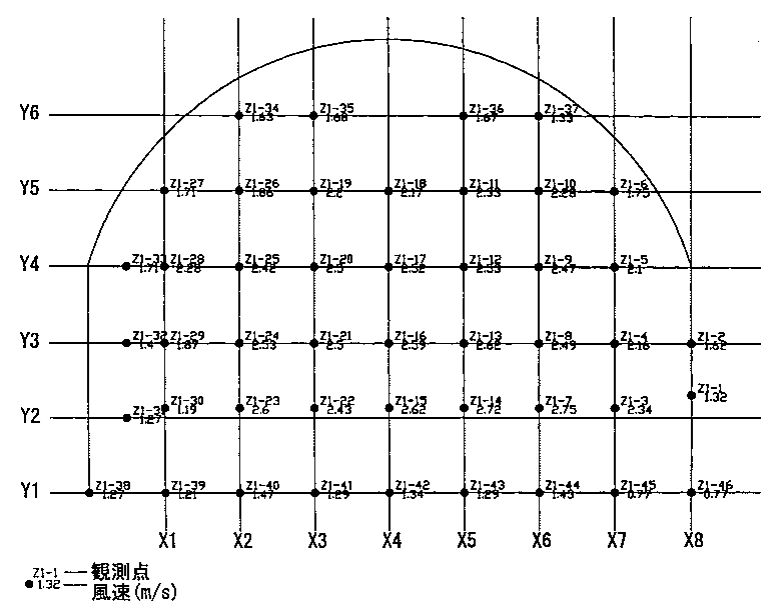

図 13 風速分布観測点位置および風速分布図

的な気流挙動を考慮できないことが課題と考えられる。

\section{6. フォローアップ}

上記の通気計画の精度を検証するため, 施工ステップ 2 の段階 において, 坑内主要箇所の通気測定を行い, フォローアップ解析 を実施した。

\section{$6 \cdot 1$ 通気測定}

$6 \cdot 1 \cdot 1$ 通気測定方法通気測定はダンプトラックの走行 による影響を避けるために連休を利用した。また，限られた時間 内でできるだけ多くの箇所の通気量を測定するため, 迅速測定が 可能な小型風速センサを開発した。指向性を高めるために直径 65 $\mathrm{mm}$ の短パイプ内にサーミスタ式センサを埋め込み, 約 2 秒ごと に風速を読みとって 30 秒間の平均風速を求めた。測定者の影響を 避けるため, 測量棒の上部にセンサを取り付けて脚立に固定し, $10 \mathrm{~m}$ 風下側においた制御箱で計測を行った ( 図 12 参照)。

なお本風速センサは, 計測範囲 $0 \sim 20.0 \mathrm{~m} / \mathrm{s}$, 測定精度 $0.1 \mathrm{~m} / \mathrm{s}$, 自動温度誤差補正機能付きの直読式センサである。市販の熱線式 風速計で誤差範囲は $0.1 \mathrm{~m} / \mathrm{s}$ 以下であることが検証されているが, 指向性の強いパイプ内の乱流による風速分布の影響や, $15 \mathrm{~m} / \mathrm{s}$ を 超えるような高風速箇所でのパイプの方向性安定維持が困難なこ となど残された課題もある。

測定箇所は分岐部の前後および分岐坑道側の 3 箇所, 局部ファ に等風速分布図を示す。

\section{$6 \cdot 2$ フォローアップ解析}

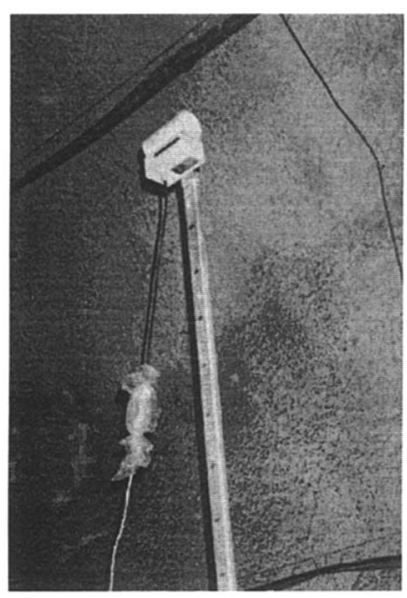

図 12 風速センサによる測定

ン前後等合計 32 箇所, 風管先 4 箇所の合計 36 箇所である。1 1 断 面における観測点は $5 \sim 3$ 点計測した。

$6 \cdot 1 \cdot 2$ 風速分布 一般に風速は断面の中央に近いほど大 きい。しかし断面形状や障害物等の影響を受け，また絶えず変動 している ${ }^{12)}$ 。そこで同一断面の多くの観測点で繰り返し計測をす ることが望ましいが，重機等が走行する現場で長時間にわたり風 速を測定することは物理的に不可能である。したがってあらかじ め断面の風速分布を測定し, 平均風速係数を求めておくと便利で ある。このため設備や重機がなく, 平滑な坑道が長く続いている 大断面の機搬坑道で, 約 $1 \mathrm{~m}$ メッシュに分割して 46 点の観測点で 通気測定を行い，平均風速係数の算出を試みた。

図 13 に測定断面の通気観測点位置図および風速を示す。これら の観測点は必ずしも同一直線上にはないため, 隣接観測点におけ る風速と補間を行い, $\mathrm{X}$ 軸と $\mathrm{Y}$ 軸の風速分布断面を求めた。図 14

この測定結果では断面下部の風速が最も高く $2.7 \mathrm{~m} / \mathrm{s}$ であり, 坑 道壁面, 特にパイプ等が敷設してある下盤際坑道壁面の風速が 0.8 $\mathrm{m} / \mathrm{s}$ と最も小さい。また坑道中央天盤際には風管が敷設してある ため風速は低下寸るはずであるが，必ずしもそのようにはなって いない。これは観測点の位置および観測点数不足, および境界条 件の設定に課題があったためと考えられる。このため局所的な誤 差を除くために断面を 9 分割し, それぞれの風速平均值と中央部 の風速に対する各断面の風速比率 (\%) を求めた (図 15 参照)。

46 点の単純平均值は $1.9 \mathrm{~m} / \mathrm{s}$ で, 坑道中央部の風速 $2.5 \mathrm{~m} / \mathrm{s}$ の 0.76 に当たるが, 最高風速 $2.7 \mathrm{~m} / \mathrm{s}$ に対しては 0.7 に止まってい る。一般にこの值は $0.8 \sim 0.88$ となる言われているが，今回の測 定結果はその数值より低い值となった。

ここで, 観測点 Z1-45, 46 は側壁下盤際や配管の裏に位置して おり, 摩擦係数と通気断面上の周囲長 (配管面等) が大きい位置に 観測点がいくつか存在していたことも上記の原因と考えられる。

以上の結果, 平均風速係数は坑道中央観測点の 0.8 とすること が適切と思われるが, 坑道断面形状や大きさ, 障害物の存在等に より変化するため, 統計的観点から観測点を設定し風速測定を行 うと共に, 断面形状の異なる坑道についても測定を行い, 平均風 速係数の精度向上を図る必要がある。

実際の建設現場においては, 施工工程や坑道仕様, 通気設備仕 様は必ずしも当初計画通りとならないことが多い。また合理的な 


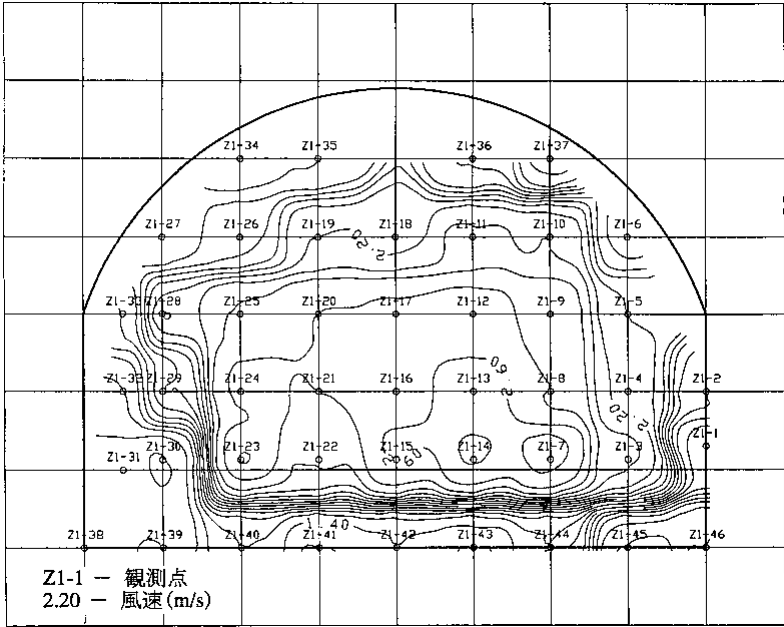

図 14 等風速分布図

通気システムと分かっていても，施工上の問題から次善の策を取 らざるを得ないこともある。本地下構築物の場合も, 施工ステッ プごとの解析に基づいて通気計画を策定した段階に比し，発電所 大空間上部の排気立坑を入気側に設置せざるを得ず，このため大 空間の通気は 2 本の局部通気を用いた原案に戻ったことを始め, 隣接共同企業体工区との通気関係が変化したり, 計画と異なった 能力のファンを用いているなど, 当初の通気計画の見直しが必要 となった。

このため, 当初は $6 \cdot 1$ で述べた通気測定を行うことで予測解析 結果を評価し, 今後の通気計画の見直しを行う予定であったが, 今回の通気測定時点の通気回路および実使用ファン特性曲線に置 き換えた解析を実施し, 通気測定結果と比較することとした。こ のとき, 小断面の主要排気坑道では風速が $10 \mathrm{~m} / \mathrm{s}$ を大幅に超えて いたため測定できなかったり, 拡幅工事残存ズリ抵抗や断面積特 定が困難な箇所等が存在したため解析に必要なパラメータを特定 できず, 補扇の風量から逆算した抵抗をこれらの坑道に与えて現 状合わせ解析を行った。

この結果, 解析パラメータについてはほぼ当初解析時点に使用 したパラメータが正しいことを検証することができた。同時に大空 間の接続坑道の入排気風量も現状に適合していたことから，疑似 三次元通気網解析が地下構築物全体の通気挙動に対し妥当である との結論を得た。次に施工ステップ 3 以降の予測解析を実施した。

\section{7. まとめと課題}

一般の地下土木構築物の換気計画においては, 切羽必要風量を 確保するためのファン容量設定を目的として，通常簡易計算によ り通気計算が行われている。しかし地下構築物が複雑化すると, 数值解析を用いた通気挙動予測が必要となる。筆者等はこのよう な観点から, 大空洞を含む複雑な坑道から構成される大規模地下 構築物について，炭鉱等鉱山で用いられている節点解法による通 気網解析手法を適用し, 施工ステップごとの通気計画を策定した。

今回の解析手法上の特徵は，下記の通りである。

(1) 空間部の解析に汎用的に用いられる数值流体力学解析 (CFD) は，モデルの構築と解析に時間を要するため多くのケース スタディを行うのは不向きであり, また民間の地下構築物の通気 設計に用いるにはコストがかかる。今回，これに代わり，大空間 の簡易な解析手法として, 疑似三次元通気網解析の大空間への適 用を試みた。

（2）大空間，通常坑道，多くの風管回路，と著しく摩擦抵抗の

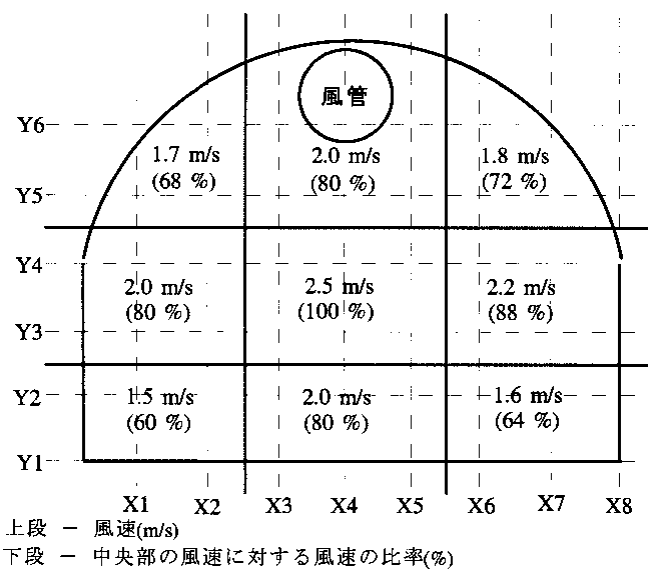

図 15 分布断面の平均風速分布

異なる通気回路を一つの解析モデルに組み込み, 施工ステップご とに解析を実施した。

この結果，当初の通気計画に対し，大型主要ファン 2 台を 1 台 に削減，ブースターファン数削減と風管長の大幅短縮，工事の進 渉に伴うファンの移設や取り替え回数の削減, 風管径の拡大によ る抵抗減でのファン能力の小容量化, 等の効果が得られ, 結果と して通気設備コスト, 電力コスト, 工数等の通気コストの大幅削 減に寄与することができた。

一方, 疑似三次元通気網解析は CFD に代わる簡易な解析手法之 して大空間の気流挙動の傾向をおおむね表現するのに有効である ことが認められたが, 動圧の影響による局所的な通気の異常な挙 動の表現ができないこと, 空間を構成寸る架空坑道の微小抵抗に よる収束性の悪化や, 空間内部の温度差による気流挙動等の課題 が存在する。微小抵抗については, 外部と繋がる系内部のすべて の坑道抵抗を同率で増加させ, 0.1 murgue 程度としたときに収束 性は安定し, また外部との風量バランスは誤差範囲に収まること が検証された。

今後, 動粘性係数を考慮した架空坑道の摩擦係数の検討, ダン プトラックのみならずすべての使用車両の排気ガスや電気機器の 発熱量, また $\mathrm{J} / \mathrm{V}$ 工事区に制限されない坑内全域の適正通気シス テムの検討などを行っていく必要がある。

今回の解析では, 従来炭鉱等で活用され技術開発がなされてき た通気網解析技術を，土木分野における大規模地下構築物に適用 を試みたものであり，いくつかの課題を残したもののその有効性 が実証され，従来の通気網解析の適用範囲を大きく広げることが できたと考えられる。同時に土木分野の地下構築物における通気 計画手法に，新たな指針を与えることができたと考える。

\section{References}

1) T. Sakai, T. Kakita and S. Tomita : Proc. MMIJ Fall Meeting (2000), Vol. I, pp. $178-$ 179.

2) Y. Mizuta, S. Asakura and N. Maeda : Proc. JSCE, Simp. of Chugoku-Sikoku Chapter (1990), pp. $138-139$

3) X. Zhang and Y. Mizuta : Suiyou-Kaishi, 22(1996), No. 6, 354-358.

4) Japan Construction Safety and Health Association : Zuidou-tou Kensetsu Kouji ni-okeru Kankigijutsu Shishin, (JCSHA, Tokyo, 2002), pp. 165-167.

5) M. Yuda : Gijutsu-Daijesuto, (Mitsui Mining Co., Ltd. and Mitsui Coal Mining Co., Ltd., Tokyo, 1980), Vol.16, No. 12, pp. 24-37.

6) N. Shikada, K. Uchino and T. Isei : Sigen-to-Sozai, 105(1989), No. 4, 285-290.

7) K. Saito and T. Sakai : Proc. MMIJ Annual Meeting (2002), Vol. I, pp. 217-218

8) O. Sakai and T. Sakai : Proc. MMIJ Annual Meeting (2001), Vol. I, pp. 97-98.

9) M. Inoue and K. Uchino : Shigen-to-Sozai, 105(1989), No.7, 532- 538.

10) Engineering Advanccement Association of Japan : Daishindo Chika Kuukan Kaihatsugijutsu no Kenkyuu Kaihatsu Seika Houkokusho, (1992), Vol. 5/10, pp.69-82.

11) S. Nakayama and N. Kameda : Shigen-to-Sozai, 118(2002), No. 1, 17-22.

12) Y. Hiramatsu: Tsuukigaku, (Uchida Roukakuho, Tokyo, 1974), pp.108-110. 